\title{
Determination of Level of Service (LOS) on Different Roads in Kuching Area (A Case study)
}

\author{
Chen, K.C. ${ }^{1}$, Larry, S.T. ${ }^{2}$
}

\begin{abstract}
The concept of Level of Service (LOS) is originated from the Highway Capacity Manual (HCM). LOS is a qualitative assessment of the operational performance of a roadway facility based on quantitative performance measures. Many transportation infrastructure funding decisions are based on LOS analysis, and LOS designations are intended to represent userperceived quality of service. This study has been carried out to determine the LOS on different roads. The profile of study area is in Kuching, Sarawak where five roads with different characteristics and posted speed of urban multilane with $80 \mathrm{~km} / \mathrm{hr}$ and $70 \mathrm{~km} / \mathrm{hr}$, suburban two-lane two-way with $90 \mathrm{~km} / \mathrm{hr}$ and $80 \mathrm{~km} / \mathrm{hr}$ had been selected for the studies. Substantial numbers of inputs are required for the LOS analysis and determination based on HCM procedures. These inputs are: a long list of traffic volume collected in different peak hours; traffic composition such as proportion of heavy vehicles in traffic; geometric characteristics such as number of lanes, lane width, shoulder width, and approach grades. Results of the study showed that LOS in the urban multilane is still in satisfactory range with LOS ranging from $C$ to $D$ except for most of the traffic congestion cases in urban multilane at the traffic light junctions and roundabouts. However, LOS in the suburban two-lane two-way is only satisfying in the range of LOS E; hence multilane should be introduced in such cases. Recommendations such as to provide various or multitude modes of transportation needs should be introduced in urban area. Furthermore, a suitable and efficient hierarchy in road system should be provided in suburban areas before turning into urban areas.
\end{abstract}

Keywords: Level of Service (LOS), traffic volume, multilane, two-lane two-way

\section{INTRODUCTION}

Level of Service (LOS) defined as a measurement of the operational conditions within a traffic stream, generally in terms of travel time, speed, freedom to maneuver, traffic interruptions, comfort and convenience (HCM, 2000). The roadway LOS is also defined as a stratification of travelers' perceptions of the quality of service provided by a facility. There are currently six letter grades from A to F that describe the LOS of a roadway facility, much like a student's report card with "A" generally representing the most favorable driving conditions and " $\mathrm{F}$ " representing the least favorable. As number of vehicles increased, traffic volume will also be increased and the increased traffic volume has further caused traffic problems such as traffic congestion. Traffic congestion is becoming a nuisance for the working class. Facing with such a situation, people cannot get to work on time or appointment on time. It causes stress, wastes precious fuel, emits dangerous emissions and takes away valuable family time. Therefore, it is strongly recommend to carry out the analysis of LOS in the majority road in city area to develop a better plan in the current traffic network to ensure that the quality of life will improved rather than becoming another source of stress.

The profile of study area is in Kuching, Sarawak. This research covers collection and analysis of data from traffic survey and observation on the traffic volume and the physical characteristics of the roadway. Studies were carried out to determine the volume capacity ratio which affects the class of the level of service. The five roads with different characteristics and posted speed that are urban multilane with $80 \mathrm{~km} / \mathrm{hr}$ and $70 \mathrm{~km} / \mathrm{hr}$, suburban two-lane two-way with 90 $\mathrm{km} / \mathrm{hr}$ and $80 \mathrm{~km} / \mathrm{hr}$ had been selected for the studies. They are namely Jalan Sherip Masahor (urban multilane with 80 $\mathrm{km} / \mathrm{hr}$ ), Jalan Datuk Bandar Mustapha (urban multilane with $70 \mathrm{~km} / \mathrm{hr}$ ), Jalan Laksamana Cheng Ho (urban multilane with $70 \mathrm{~km} / \mathrm{hr}$ ), Jalan Datuk Amar Kalong Ningkan Batu Kawa By-Pass Road (suburban two-lane two-way with $80 \mathrm{~km} / \mathrm{hr}$ ), Jalan Kuching-Serian road from 11/1/2th Mile to 15th Mile two-lane segment road (rural two-lane two-way with $90 \mathrm{~km} / \mathrm{hr}$ ).

\section{LITERATURE REVIEW}

The Highway Capacity Manual (HCM) is recognized as the primary source of document on the Level of Service (LOS) and quality of service for roads in the U.S. The concept of six levels of service to describe the quality of road operations using an A to F letter scale first appeared in the $1965 \mathrm{HCM}$. The levels of service were presented as being based on perceptions of the individual road user and the document recognized that the user has little realization of traffic volume itself.

1 Student, Department of Civil Engineering, Faculty of Engineering, Universiti Malaysia Sarawak, Sarawak, Malaysia,

2 Lecturer, Department of Civil Engineering, Faculty of Engineering, , Universiti Malaysia Sarawak, Sarawak, Malaysia , stlarry@feng.unimas. 
The level of service concept caught on so well that not only do highway engineers use the concept, but lay people (i.e., elected officials) to this day routinely use it to describe roadway operations. An "F" for Automobile LOS means heavy congestion and slow moving traffic, but an " $\mathrm{A}$ " for Automobile LOS means no congestion and smooth moving traffic. It is connected to the physical characteristics of the roadway as it resolves the road capacity, and the different operating characteristics that can occur when the roadway carries different traffic volumes.

The Highway Capacity Manual (HCM) and American Association of State Highway and Transportation Officials (AASHTO) - Geometric Design of Highways and Streets "Green Book" list the following levels of service given in Table 1 below:

Table 1: Types of Level of Service (LOS) Condition

\begin{tabular}{|c|c|}
\hline Level Of Service (LOS) & Condition \\
\hline A & Free flow \\
\hline B & Reasonably free flow \\
\hline C & Stable flow \\
\hline D & Approaching unstable flow \\
\hline E & Unstable flow \\
\hline F & Forced or breakdown flow \\
\hline
\end{tabular}

\section{Methodology}

Road inventories (geometric data) and detailed peak period traffic counts (traffic volumes) at each road provide the necessary data to determine levels of traffic service that exist at present. These two main sources are consider as traffic survey in the first phase of LOS Operation Framework in both Multilane and Two-lane LOS as shown in figures 1 and 2. The substantial numbers of data inputs in the first phase are required for the LOS analysis and determination according to the Highway Capacity Manual (HCM) procedures. The geometric data and traffic volumes at each road are required at each of the directional lanes. This is to examine the current trend of directional traffic flows through the roads system. The manual counts technique was selected in this case study project. The manual count is the easiest method, using manpower's (at least 3 people) and simple equipment to jot down reading such as pen and paper.

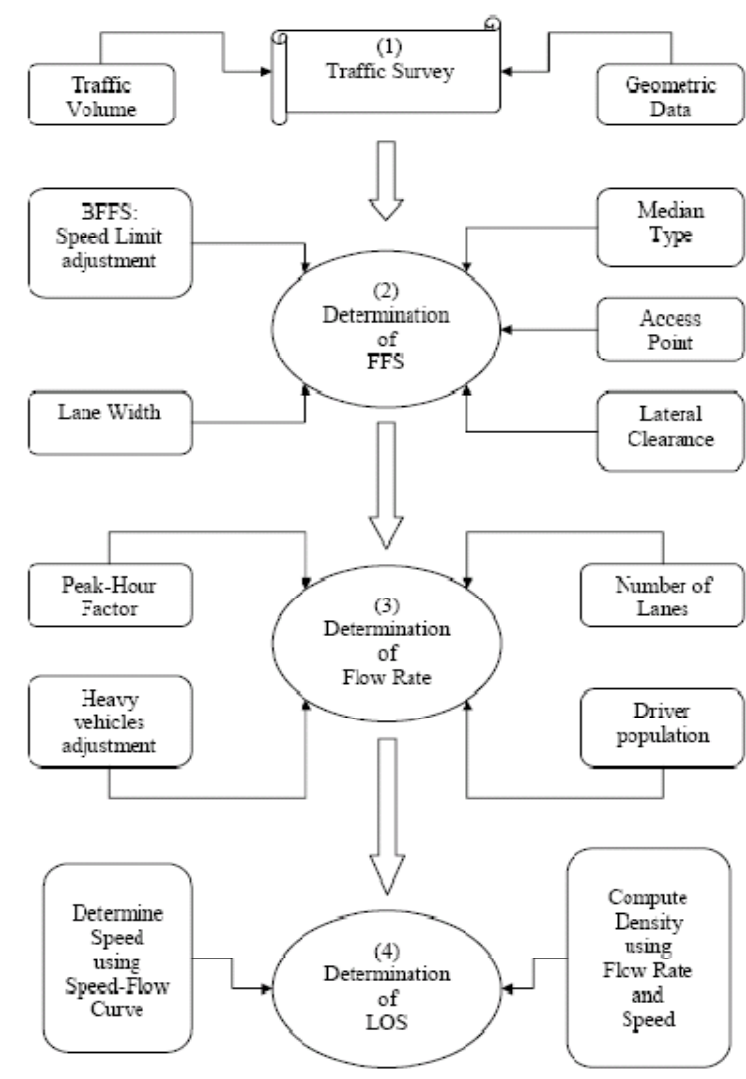

Figure 1: Multilane LOS Operation Framework (Source: HCM, 2000)

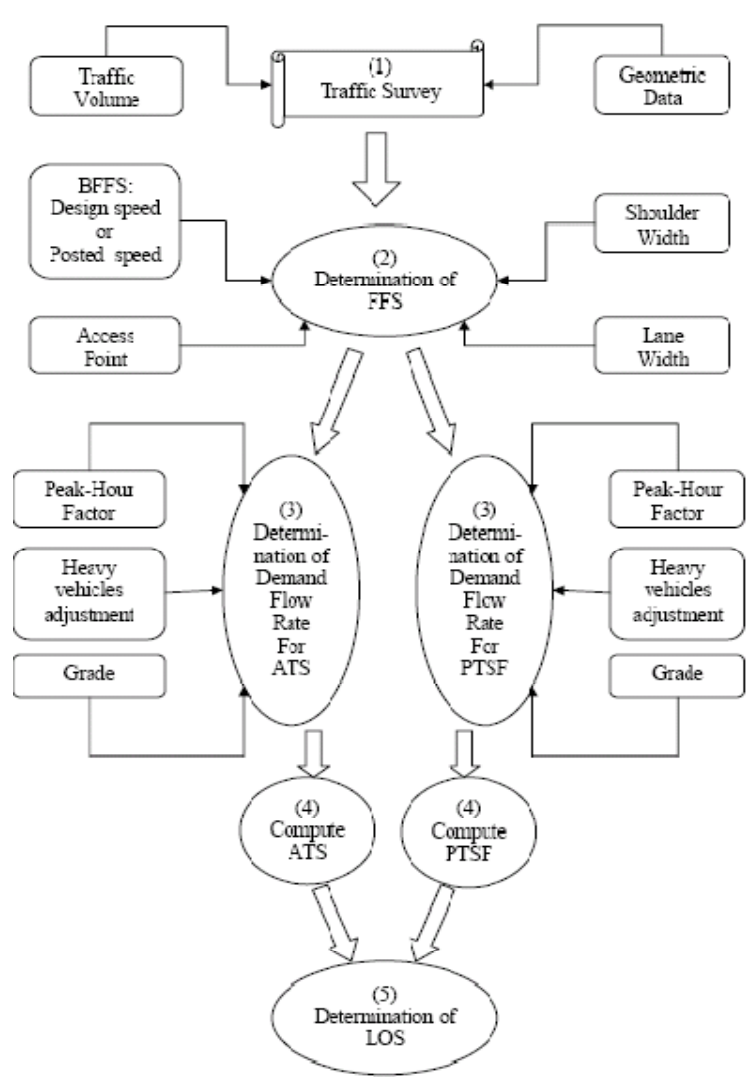

Figure 2: Two-lane LOS Operation Framework (Source: HCM, 2000) 
Most volume studies that involve manual counts are taken in peak periods that include the heaviest hours of morning, afternoon, and evening traffic; the counting period may depend upon the method used to obtain data and the planned use of the data. Counts are normally not conducted during special conditions such as holidays, sporting events, transit strikes, special sales, unusual weather or temporary street closures, unless the count is for the specific purpose of studying the effects of these special conditions. While doing this manual counting, observer must be positioned where they have a clear view of the traffic. Observer should be positioned away from the edge of the roadway. If observers are positioned above ground level and clear of obstructions they usually have the best vantage point. Visual contact must be maintained if there are multiple observers at a site.

The Time of traffic surveys are taken in the peak periods on weekday's morning (7am to 9am), afternoon (12pm to $1 \mathrm{pm})$, and evening $(4.45 \mathrm{pm}$ to $6.45 \mathrm{pm})$. The traffic was recorded at every 15 -minute interval under five different vehicle categories namely: passenger car, motorcycle, lorry, large lorry, and bus. One hour was selected from the heaviest peak hours for the analysis of LOS since the substantial short-term fluctuations typically occur during an hour. Geometric characteristics parameters such as number of lanes, no. of access points along the road, lane width, shoulder width, and approach grades in every road are taken as the road elements need to be considered in the LOS study.

Besides the first phase of traffic survey, other three phases of process required to determine multilane LOS are: firstly, determination of Free-Flow Speed (FFS) which is the mean speed of traffic as measured when flow rates are in the range of low to moderate; secondly, determination of Flow Rate which is the peak hour volume adjusted for the temporal variation of traffic demand within the analysis hour, the impacts due to heavy vehicles, and characteristics of the driving population; finally, the determination of LOS grade and its density. Meanwhile, other four phases of process to determine two-lane two-way LOS are: firstly, determination of Free-Flow Speed (FFS); secondly, determination of Demand Flow Rate based on hourly demand volumes from traffic counts or estimates; thirdly, compute Average Travel Speed (ATS) and Percent-Time-Spend-Following (PTSF); finally, the determination of LOS grade and its volume capacity ratio (v/c).

\section{Traffic SuRVEy Result}

Traffic survey result data shown from table 1 until

$$
\text { a. Jalan Sherip Masahor }
$$

Table 1: Daily Peak Hour Volume in Peak Direction

\begin{tabular}{|c|c|c|c|c|c|c|c|c|c|}
\hline Date: & $9 / 12 / 2008$ & \multicolumn{2}{|c|}{ Road: } & \multicolumn{6}{|c|}{ Jln. Sherip Masahor (multilane) } \\
\hline Table: & $\mathbf{1}$ & \multicolumn{2}{|c|}{ Direction: } & \multicolumn{6}{|c|}{$\mathrm{BDC}$ to 3 rd Mile } \\
\hline \multicolumn{10}{|c|}{ Peak Hour (7.30am - 8.30am) } \\
\hline \multirow[b]{3}{*}{$\begin{array}{c}\text { Time } \\
\text { Interval }\end{array}$} & \multicolumn{7}{|c|}{ Vehicle Classification } & \multirow[b]{3}{*}{$\begin{array}{c}\text { Total } \\
\text { Vehicles }\end{array}$} & \multirow{3}{*}{$\begin{array}{c}\text { Total } \\
\text { Vehicles } \\
\text { (veh/hr) }\end{array}$} \\
\hline & 1 & 2 & \multirow{2}{*}{\multicolumn{2}{|c|}{$\begin{array}{c}3 \\
\text { Large } \\
\text { Lorries }\end{array}$}} & 4 & \multicolumn{2}{|c|}{5} & & \\
\hline & $\begin{array}{c}\text { Passenger } \\
\text { Cars }\end{array}$ & Lorries & & & Buses & $\begin{array}{l}\text { Motor } \\
\text { cycles }\end{array}$ & PCE & & \\
\hline $7.30-7.45$ & 311 & 4 & 0 & & 2 & 53 & 40 & 357 & 1428 \\
\hline $7.45-8.00$ & 400 & 6 & 2 & & 0 & 70 & 53 & 461 & 1844 \\
\hline $8.00-8.15$ & 328 & 4 & 0 & & 0 & 58 & 44 & 376 & 1504 \\
\hline $8.15-8.30$ & 305 & 8 & 2 & & 0 & 46 & 35 & 350 & 1400 \\
\hline $\begin{array}{c}\text { Total } \\
\text { Vehicles }\end{array}$ & 1344 & 22 & 4 & & 2 & 227 & 172 & 1544 & \\
\hline
\end{tabular}

\section{b. Jalan Datuk Bandar Mustapha}

Table 3: Daily Peak Hour Volume in Peak Direction

\begin{tabular}{|c|c|c|c|c|c|c|c|c|}
\hline Date: & $11 / 12 / 2008$ & \multicolumn{2}{|c|}{ Road: } & \multicolumn{5}{|c|}{ Jln. Datuk Bandar Mustapha (multilane) } \\
\hline Table: & 1 & \multicolumn{2}{|c|}{ Direction: } & \multicolumn{5}{|c|}{$4^{1 / 2}$ th Mile to BDC } \\
\hline \multicolumn{9}{|c|}{ Peak Hour (7.15am - 8.15am) } \\
\hline \multirow[b]{3}{*}{$\begin{array}{c}\text { Time } \\
\text { Interval }\end{array}$} & \multicolumn{6}{|c|}{ Vehicle Classification } & \multirow[b]{3}{*}{$\begin{array}{c}\text { Total } \\
\text { Vehicles }\end{array}$} & \multirow{3}{*}{$\begin{array}{l}\text { Total } \\
\text { Vehicles } \\
\text { (veh/hr) }\end{array}$} \\
\hline & 1 & 2 & \multirow{2}{*}{$\begin{array}{c}3 \\
\text { Large } \\
\text { Lorries }\end{array}$} & 4 & \multicolumn{2}{|c|}{5} & & \\
\hline & $\begin{array}{c}\text { Passenger } \\
\text { Cars }\end{array}$ & Lorries & & Buses & $\begin{array}{l}\text { Motor } \\
\text { cycles }\end{array}$ & PCE & & \\
\hline $7.30-7.45$ & 352 & 24 & 8 & 0 & 138 & 104 & 488 & 1952 \\
\hline $7.45-8.00$ & 349 & 20 & 7 & 0 & 108 & 81 & 457 & 1828 \\
\hline $8.00-8.15$ & 382 & 16 & 6 & 0 & 109 & 82 & 486 & 1944 \\
\hline $8.15-8.30$ & 366 & 42 & 17 & 0 & 76 & 57 & 482 & 1928 \\
\hline $\begin{array}{c}\text { Total } \\
\text { Vehicles }\end{array}$ & 1449 & 102 & 38 & 0 & 431 & 324 & 1913 & \\
\hline
\end{tabular}

Table 2: General and Specific Data

\begin{tabular}{|c|c|}
\hline Traffic Stream Type: & Weekday \\
\hline Peak Hour Volume: & $1544 \mathrm{veh} / \mathrm{hr}$ \\
\hline Percentage of Trucks and Buses $\left(P_{T}\right):$ & $1.82 \%$ \\
\hline Percentage of Recreational Vehicles $\left(P_{R}\right):$ & $0 \%$ \\
\hline Peak Hour Factor $(\mathrm{PHF}):$ & 0.83 \\
\hline Terrain Type: & Level \\
\hline No. of Lanes $(\mathrm{N}):$ & 2 \\
\hline Lane Width: & $3.65 \mathrm{~m}$ \\
\hline Shoulder Width $\left(L C_{L}\right):$ & $0.7 \mathrm{~m}$ \\
\hline Median Shoulder Width $\left(L C_{R}\right):$ & $0.5 \mathrm{~m}$ \\
\hline Median Type: & $\mathrm{Divided}$ \\
\hline Posted Speed: & $80 \mathrm{~km} / \mathrm{hr}$ \\
\hline Access Points per km: & 8 \\
\hline
\end{tabular}

Table 4: General and Specific Data

\begin{tabular}{|c|c|}
\hline Traffic Stream Type: & Weekday \\
\hline Peak Hour Volume: & $1913 \mathrm{veh} / \mathrm{hr}$ \\
\hline Percentage of Trucks and Buses $\left(P_{T}\right):$ & $7.32 \%$ \\
\hline Percentage of Recreational Vehicles $\left(P_{R}\right):$ & $0 \%$ \\
\hline Peak Hour Factor $($ PHF): & 0.98 \\
\hline Terrain Type: & Level \\
\hline No. of Lanes $(\mathrm{N}):$ & 2 \\
\hline Lane Width: & $3.65 \mathrm{~m}$ \\
\hline Shoulder Width $\left(L C_{L}\right):$ & $\geq 1.8 \mathrm{~m}$ \\
\hline Median Shoulder Width $\left(L C_{R}\right):$ & $0.6 \mathrm{~m}$ \\
\hline Median Type: & Divided \\
\hline Posted Speed: & $70 \mathrm{~km} / \mathrm{hr}$ \\
\hline Access Points per km: & 4 \\
\hline
\end{tabular}




\section{c. Jalan Laksamana Cheng Ho}

Table 5: Daily Peak Hour Volume in Peak Direction

\begin{tabular}{|c|c|c|c|c|c|c|c|c|c|}
\hline Date: & $17 / 12 / 2008$ & \multicolumn{2}{|c|}{ Road: } & \multicolumn{6}{|c|}{ Jln. Laksamana Cheng Ho (multilane) } \\
\hline Table: & 3 & \multicolumn{2}{|c|}{ Direction: } & \multicolumn{6}{|c|}{$21 / 2$ th Mile to Jln. Tun Jugah } \\
\hline \multicolumn{10}{|c|}{ Peak Hour (5.15pm - 6.15pm) } \\
\hline \multirow[b]{3}{*}{$\begin{array}{c}\text { Time } \\
\text { Interval }\end{array}$} & \multicolumn{7}{|c|}{ Vehicle Classification } & \multirow[b]{3}{*}{$\begin{array}{c}\text { Total } \\
\text { Vehicles }\end{array}$} & \multirow{3}{*}{$\begin{array}{c}\text { Total } \\
\text { Vehicles } \\
\text { (veh/hr) }\end{array}$} \\
\hline & 1 & 2 & \multirow{2}{*}{\multicolumn{2}{|c|}{$\begin{array}{c}3 \\
\text { Large } \\
\text { Lorries }\end{array}$}} & 4 & \multicolumn{2}{|c|}{5} & & \\
\hline & $\begin{array}{c}\text { Passenger } \\
\text { Cars }\end{array}$ & Lorries & & & Buses & $\begin{array}{l}\text { Motor } \\
\text { cycles }\end{array}$ & PCE & & \\
\hline $5.15-5.30$ & 488 & 20 & 0 & & 0 & 108 & 81 & 589 & 2356 \\
\hline $5.30-5.45$ & 520 & 18 & 3 & & 0 & 115 & 87 & 628 & 2512 \\
\hline $5.45-6.00$ & 506 & 18 & 2 & & 0 & 81 & 61 & 587 & 2348 \\
\hline $6.00-6.15$ & 507 & 9 & 0 & & 0 & 72 & 54 & 570 & 2280 \\
\hline $\begin{array}{c}\text { Total } \\
\text { Vehicles }\end{array}$ & 2021 & 65 & 5 & & 0 & 376 & 283 & 2374 & \\
\hline
\end{tabular}

Table 6: General and Specific Data

\begin{tabular}{|c|c|}
\hline Traffic Stream Type: & Weekday \\
\hline Peak Hour Volume: & $2374 \mathrm{veh} / \mathrm{hr}$ \\
\hline Percentage of Trucks and Buses $\left(P_{T}\right):$ & $2.95 \%$ \\
\hline Percentage of Recreational Vehicles $\left(P_{R}\right):$ & $0 \%$ \\
\hline Peak Hour Factor $(\mathrm{PHF}):$ & 0.94 \\
\hline Terrain Type: & Level \\
\hline No. of Lanes $(\mathrm{N}):$ & 2 \\
\hline Lane Width: & $3.6 \mathrm{~m}$ \\
\hline Shoulder Width $\left(L C_{L}\right):$ & $0.7 \mathrm{~m}$ \\
\hline Median Shoulder Width $\left(L C_{R}\right):$ & $0.5 \mathrm{~m}$ \\
\hline Median Type: & Divided \\
\hline Posted Speed: & $70 \mathrm{~km} / \mathrm{hr}$ \\
\hline Access Points per km: & 8 \\
\hline
\end{tabular}

\section{d. Jalan Datuk Amar Kalong Ningkan (Two-lane Batu-Kawa By-pass Road)}

Table 7: Daily Peak Hour Volume in Both Direction

\begin{tabular}{|c|c|c|c|c|c|c|c|c|}
\hline Date: & $10 / 12 / 2008$ & \multicolumn{2}{|c|}{ Road: } & \multicolumn{5}{|c|}{ Jln. Datuk Amar Kalong Ningkan (two-lane) } \\
\hline Table: & $1 \& 4$ & \multicolumn{2}{|c|}{ Direction: } & \multicolumn{5}{|c|}{ Both Direction } \\
\hline \multicolumn{9}{|c|}{ Peak Hour (7.15am - 8.15am) } \\
\hline \multirow[b]{3}{*}{$\begin{array}{c}\text { Time } \\
\text { Interval }\end{array}$} & \multicolumn{6}{|c|}{ Vehicle Classification } & \multirow[b]{3}{*}{$\begin{array}{c}\text { Total } \\
\text { Vehicles }\end{array}$} & \multirow{3}{*}{$\begin{array}{c}\text { Total } \\
\text { Vehicles } \\
\text { (veh/hr) }\end{array}$} \\
\hline & 1 & 2 & \multirow{2}{*}{$\begin{array}{c}3 \\
\text { Large } \\
\text { Lorries }\end{array}$} & 4 & \multicolumn{2}{|c|}{5} & & \\
\hline & $\begin{array}{c}\text { Passenger } \\
\text { Cars }\end{array}$ & Lorries & & Buses & $\begin{array}{l}\text { Motor } \\
\text { cycles }\end{array}$ & PCE & & \\
\hline $7.15-7.30$ & 425 & 15 & 10 & 1 & 146 & 110 & 561 & 2244 \\
\hline $7.30-7.45$ & 432 & 15 & 10 & 0 & 135 & 102 & 559 & 2236 \\
\hline $7.45-8.00$ & 481 & 21 & 21 & 1 & 149 & 112 & 636 & 2544 \\
\hline $8.00-8.15$ & 383 & 24 & 14 & 0 & 107 & 81 & 502 & 2008 \\
\hline $\begin{array}{c}\text { Total } \\
\text { Vehicles }\end{array}$ & 1721 & 75 & 55 & 2 & 537 & 405 & 2258 & \\
\hline
\end{tabular}

e. Jalan Kuching-Serian (Two-lane segment from $10^{1 / 2}{ }^{\text {th }}$ Mile to $15^{\text {th }}$ Mile)

Table 9: Daily Peak Hour Volume in Both Direction

\begin{tabular}{|c|c|c|c|c|c|c|c|c|c|}
\hline Date: & $16 / 12 / 2008$ & \multicolumn{2}{|c|}{ Road: } & \multicolumn{6}{|c|}{ Jln. Kuching-Serian (two-lane) } \\
\hline Table: & $1 \& 4$ & \multicolumn{2}{|c|}{ Direction: } & \multicolumn{6}{|c|}{ Both Direction } \\
\hline \multicolumn{10}{|c|}{ Peak Hour (7.15am - 8.15am) } \\
\hline \multirow[b]{3}{*}{$\begin{array}{c}\text { Time } \\
\text { Interval }\end{array}$} & \multicolumn{7}{|c|}{ Vehicle Classification } & \multirow[b]{3}{*}{$\begin{array}{c}\text { Total } \\
\text { Vehicles }\end{array}$} & \multirow{3}{*}{$\begin{array}{c}\text { Total } \\
\text { Vehicles } \\
\text { (veh/hr) }\end{array}$} \\
\hline & 1 & 2 & \multirow{2}{*}{\multicolumn{2}{|c|}{$\begin{array}{c}3 \\
\text { Large } \\
\text { Lorries }\end{array}$}} & 4 & \multicolumn{2}{|c|}{5} & & \\
\hline & $\begin{array}{c}\text { Passenger } \\
\text { Cars }\end{array}$ & Lorries & & & Buses & \begin{tabular}{|l|} 
Motor \\
cycles
\end{tabular} & PCE & & \\
\hline $7.15-7.30$ & 314 & 9 & 1 & & 4 & 163 & 163 & 491 & 1964 \\
\hline $7.30-7.45$ & 375 & 15 & 4 & & 2 & 209 & 209 & 605 & 2420 \\
\hline $7.45-8.00$ & 361 & 22 & 3 & & 5 & 241 & 241 & 632 & 2528 \\
\hline $8.00-8.15$ & 318 & 17 & 1 & & 2 & 220 & 220 & 558 & 2232 \\
\hline $\begin{array}{c}\text { Total } \\
\text { Vehicles }\end{array}$ & 1368 & 63 & 9 & & 13 & 833 & 833 & 2286 & \\
\hline
\end{tabular}

Table 8: General and Specific Data

\begin{tabular}{|c|c|}
\hline Traffic Stream Type: & Weekday \\
\hline Peak Hour Volume (Two-Way Volume): & $2258 \mathrm{veh} / \mathrm{hr}$ \\
\hline Percentage of Trucks and Buses $\left(P_{T}\right):$ & $5.85 \%$ \\
\hline Percentage of Recreational Vehicles $\left(P_{R}\right):$ & $0 \%$ \\
\hline Peak Hour Factor (PHF): & 0.89 \\
\hline Terrain Type (Grade): & Level \\
\hline Directional Split: & $67 / 33$ \\
\hline Lane Width: & $3.65 \mathrm{~m}$ \\
\hline Shoulder Width: & $\geq 1.8 \mathrm{~m}$ \\
\hline Percentage of No-Passing Zones: & $0 \%$ \\
\hline Posted Speed: & $80 \mathrm{~km} / \mathrm{hr}$ \\
\hline Class Type: & $\mathrm{I}$ \\
\hline Access Points per km: & 4 \\
\hline
\end{tabular}

Table 10: General and Specific Data

\begin{tabular}{|c|c|}
\hline Traffic Stream Type: & Weekday \\
\hline Peak Hour Volume (Two-Way Volume): & $2286 \mathrm{veh} / \mathrm{hr}$ \\
\hline Percentage of Trucks and Buses $\left(P_{T}\right):$ & $3.72 \%$ \\
\hline Percentage of Recreational Vehicles $\left(P_{R}\right):$ & $0 \%$ \\
\hline Peak Hour Factor (PHF): & 0.91 \\
\hline Terrain Type (Grade): & Level \\
\hline Directional Split: & $71 / 29$ \\
\hline Lane Width: & $3.45 \mathrm{~m}$ \\
\hline Shoulder Width: & $\geq 1.8 \mathrm{~m}$ \\
\hline Percentage of No-Passing Zones: & $0 \%$ \\
\hline Posted Speed: & $90 \mathrm{~km} / \mathrm{hr}$ \\
\hline Class Type: & $\mathrm{I}$ \\
\hline Access Points per km: & 20 \\
\hline
\end{tabular}




\section{LOS ANALYSIS RESULT}

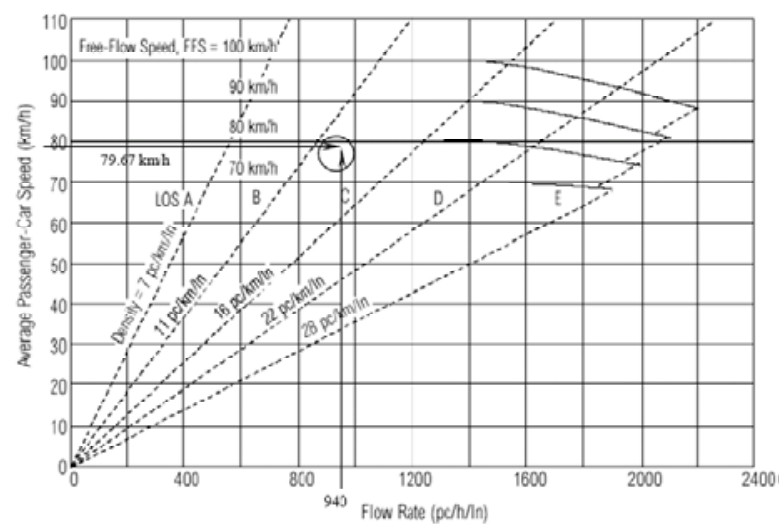

Figure 3: Multilane LOS Range in Jln. Sherip Masahor

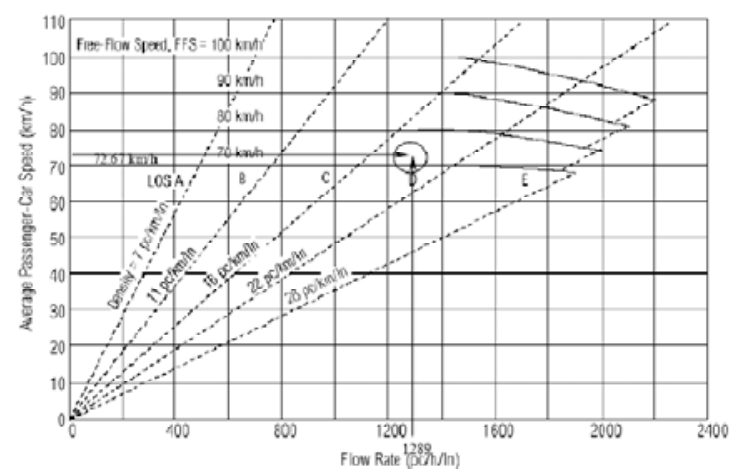

Figure 5: Multilane LOS Range in Jalan Laksamana Cheng Ho

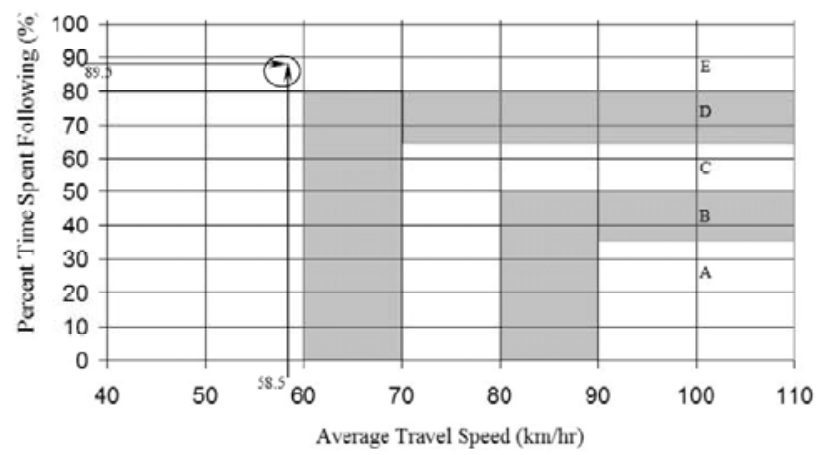

Figure 6: Two-lane LOS Range in Jalan Datuk Amar Kalong Ningkan (Two Lane Batu-Kawa By-pass Road)

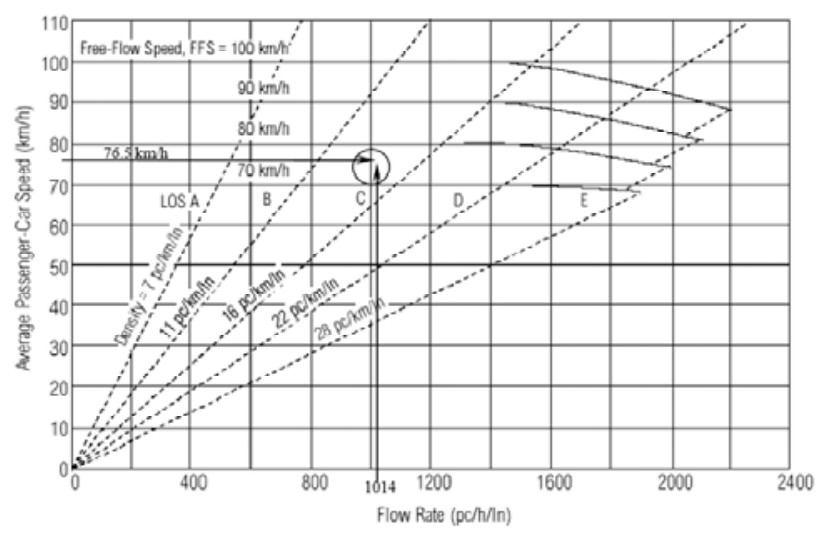

Figure 4: Multilane LOS Range in Jln. Dtk. Bandar Mustapha

From the finding obtained, LOS in the urban multilane such as Jalan Sherip Masahor and Jalan Datuk Bandar Mustapha are still satisfactory in the range of LOS $\mathrm{C}$ grade while Jalan Laksamana Cheng Ho is satisfactory in the range of LOS D grade except the congestion areas at the traffic light junctions and roundabouts. Whereby the minimum design level of service is D in urban highway.

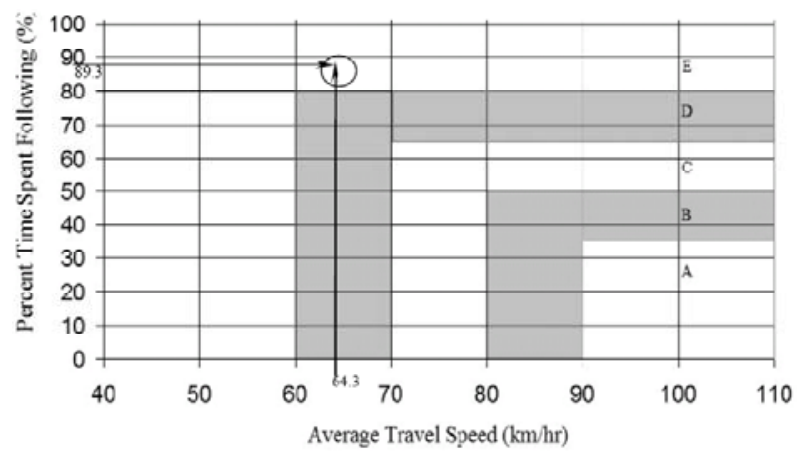

Figure 7: Two-lane LOS Range in Jalan Kuching-Serian $\left(1012^{\text {th }}\right.$ Mile to $15^{\text {th }}$ Mile)

However, LOS in the suburban and rural two-lane two-way such as Jalan Datuk Amar Kalong Ningkan and Jalan Kuching-Serian are only satisfying in the range of LOS E grade, hence multilane should be introduced in such cases.

\section{CONCLUSION AND RECOMMENDATION}

Traffic operational analysis is needed to evaluate the Level of Service (LOS) of a road section to sustain traffic demand. The LOS provides a qualitative ranking of the traffic operational conditions for the road user. Current practice in road performance analysis is based on the method stimulated in the American Highway Capacity Manual (HCM, 2000). Based on HCM 2000, the performance of road sections is evaluated using capacity analysis, which evaluate the road performance in term of traffic conditions based on six grades of LOS from A to F. LOS A representing the best operating conditions whereby LOS F represents the worst scenario. Each LOS represents a range of operating conditions and the driver's perception on those conditions. Safety is not included in the measurements of establishing the service levels. 
It can be summarized that Level of Service (LOS) of three roads in the area of Kuching are still in satisfactory level ranging from LOS C to D. Most case of the traffic congestion is happen in urban multilane traffic light junction (signalized intersection) and roundabout. In these cases of problems, further case studies on determination of LOS in intersection and roundabout are recommended to be carried out. Moreover, in the finding of LOS in intersection and roundabout, there will be a set of warrant to decide so as to improve the facility from roundabout to signalized intersection or to grade separated intersection (interchange). Besides upgrade from the signalized intersection into grade separated intersection which is highly expensive, another mitigation method on traffic congestion in signalized intersection is by providing a systematic traffic control system. The systematic traffic control system is the green wave idea in every close linked signalized intersection. This green wave idea means there will be a traffic green light wave in every close linked signalized intersection followed by one another when people travel from one point of signalized intersection to another. These mitigations would greatly assure in reducing the traffic congestion problem as well as increasing the LOS grade.

In fact, from the data obtained, the current multilane LOS in Kuching urban area in peak hour already reached grade D of LOS, and these LOS grades will further deteriorate when traffic volume increases in the future. The mitigation method such as increasing the number of lanes in the multilane road facility in the urban area will be difficult to be carried out due to many existing roadside development, underground cable, utility, building etc. which are also costly to remove. Thus, mitigation or is required to be carried out to decrease the traffic volumes for current and future needs to consider services such as to provide various or multitude modes of transportation for various needs or demands.

Meanwhile, from this study in the suburban and rural area of Kuching, the current two-lane two-way road has already reached grade $\mathrm{E}$ of LOS. Therefore, it is highly recommended to upgrade these road facility into multilane while there is still less development on the roadside. Alternative highway or more roads with proper traffic plans using hierarchy system should be constructed to avoid traffic congestion problem by giving the driver more alternatives to reach their destination instead of depending on one road only. Besides, it is easy to provide a suitable and efficient hierarchy on the road system in these areas before turning them into urban area.

With these recommendations, the design of road system must be changed or redesigned by traffic engineer especially in terms of number of lanes per direction which need to be increased. Therefore, future studies and projects should be implemented with the following mitigation such as: to propose a suitable and efficient hierarchy road system in rural and suburban areas; to provide a systematic traffic control system in the urban area; and to provide various or multitude modes of transportation needs or demands.

\section{REFERENCES}

[1] Cawangan Jalan,Ibu Pejabat JKR. (1995). GENERAL INFORMATION ON MALAYSIAN ROADS. Retrieve Jul. 17, 2008, from http://www.jkr.gov.my/jln/hari-jkr/road1.htm

[2] Currin, T.R. (2001). Introduction to Traffic Engineering: A Manual for Data Collection and Analysis. First Edition. Wadsworth Group: Brooks/Cole.

[3] Garber, N. J. and Hoel, L. A. (2002). Traffic and Highway Engineering. Third Edition. Pacific Grove, CA : Brooks/Cole Pub. Co.

[4] Highway Capacity Manual (2000). Transportation Research Board, National Research Council, Washington, DC.

[5] Jabatan Kerja Raya. (2004). Road Branch Department JKR. Retrieve Jul. 17, 2008, from http://rakan1.jkr.gov.my/cjalan/index.php

[6] Jabatan Pengangkutan Jalan Malaysia. Statistik Pengangkutan Darat oleh Kementerian Pengangkutan. Ministry of Transport. (2008). Retrieve Jul. 18, 2008, from http://www.mot.gov.my/BM/stat/darat.htm

[7] Pignataro, L. J. (1973). Traffic Engineering: Theory and Practice. First Edition. New Jersey: Prentice Hall

[8] REAM GL 2/2002. A Guide on Geometric Design of Roads. Road Engineering Association of Malaysia.

[9] Steve, and Yvonne. (2003). Freeway \& Highway Level of Service. Retrieve Aug. 02, 2008. from http://courses.washington.edu/cee $320 \mathrm{w}$

[10] Stout, T. B. (2002). Capacity Analysis. Retrieve Aug. 01, 2008. from http://www.ctre.iastate.edu/educweb/ce453

[11] Taylor, M. A. P., Young, W., and Bonsall, P. W. (2000). Understanding Traffic Systems: Data, Analysis, and Presentation. Second Edition. Aldershot, Hants : Ashgate

[12] Traffic Study Report for "Naiktaraf Persimpangan BDC / Jalan Tun Jugah dan Membina Jalan Hubung Lapangan Terbang Antarabangsa Kuching / Stutong". Prepared by L \& P Associates. July 2006.

[13] Transportation Research Board. (2008). TRB E-Newsletter Search Results. Retrieve Aug. 25, 2008. from http://www.trb.org/news/search news.asp?day=30\&t=2::Recently\%20Released $\% 20 \% 20$ TRB $\% 20 \% 20$ Publications

[14] WikiMapia. Imagery (C2009 TerraMetrics. Retrieve Feb. 12, 2009. from http://wikimapia.org 